\title{
Synthesis and thermal study of new $N$-substituted 1H-pyrrolo[3,4-c]pyridine-1,3(2H)diones of Mannich base type
}

\author{
Edward Krzyżak • Berenika Szczęśniak-Sięga • \\ Dominika Szkatuła $\cdot$ Wiesław Malinka
}

Received: 4 April 2011/Accepted: 20 June 2011/Published online: 17 July 2011

(C) The Author(s) 2011. This article is published with open access at Springerlink.com

\begin{abstract}
The new derivatives of 3,4-pyridinedicarboximide were synthesised. Experimental measurements were carried out using ${ }^{1} \mathrm{H}$ NMR spectra, IR spectra, elemental analyses and differential scanning calorimetry. The purpose of this study was to study the thermal stability of these four new compounds and to establish a solid-state polymorphism. Measurements were carried out for samples obtained from ethanol and $n$-hexane and after a long-time storage.
\end{abstract}

Keywords DSC · Polymorphism .

Pyridinedicarboximide - Thermal stability

\section{Introduction}

It was reported previously that the derivatives of 3,4-pyridinedicarboximide cause in animal tests significant analgesic activity and do not display any noticeable toxic effects $\left(\mathrm{LD}_{50}>2000 \mathrm{mg} / \mathrm{kg}\right)$ [1-3]. Over the last decade, many similar compounds with structural modifications have been synthesised. The relationship between structure and pharmacological properties were investigated $[4,5]$. In the 'writhing syndrome' and 'hot plate' tests of those

\section{E. Krzyżak ( $\bowtie)$}

Department of Inorganic Chemistry, Wrocław Medical

University, ul. Szewska 38, 50-139 Wrocław, Poland

e-mail: edward.krzyzak@am.wroc.pl

B. Szczęśniak-Sięga $\cdot$ D. Szkatuła · W. Malinka Department of Chemistry of Drugs, Wrocław Medical University, ul. Tamka 1, 50-137 Wrocław, Poland compounds, they have exhibited potent analgesic activity, which was superior to that of acetylsalicylic acid. What's more, the results of the 'writhing syndrome' test indicate that the same compounds were more potent than morphine. Furthermore, most of the investigated imides suppressed significantly spontaneous locomotor activity in mice and prolonged barbiturate sleep of these animals. The results of the preliminary radioligand binding assay suggest that these compounds display a weak affinity (in micromolar concentration) to $\mu$-opioid receptors.

It would be of considerable importance to undertake studies aiming at evaluation of the stability of that group of compounds. A kinetic study of the degradation in aqueous solution has shown that, either an acidic or basic medium, at an increasing temperature, hydrolysis of the imide bonds is observed [6-8]. However, solid form diversity of pharmaceutical substances may influence the efficacy and safety of drug products. Physical and chemical characterization of different solid phases that may occur during crystallization and pharmaceutical formulation processes, i.e. polymorphs, pseudo-polymorphism, solvates, desolvated solvates and amorphous materials is therefore advisable for both drugs and excipients. It is very important to control the crystal form of the drug during the various stages of drug development, because any phase changes and change in the degree of crystallinity can alter the bioavailability of the drug. Thermal analysis is one of the most frequently used instrumental techniques on pharmaceutical researches to solve technological problems [9-12]. The thermal analysis methods are widely used for the study of the stability and decomposition of the substances used in medicine [13-25]. The evaluation of the stability of a drug in solid form is realized especially by analysing its decomposition in isothermal and non-isothermal conditions. 


\section{Experimental}

\section{Materials}

The four new derivatives of 3,4-pyridinedicarboximide were synthesised (Fig. 1). A $0.5 \mathrm{~g}(0.002 \mathrm{~mol})$ of 4-methoxy or 4-ethoxy-2,3-dihydro-6-methyl-1,3-dioxo-1H-pyrrolo[3,4c]pyridine was dissolved in $40 \mathrm{~cm}^{3}$ of tetrahydrofurane and to this solution $1 \mathrm{~cm}^{3}$ of $33 \%$ formaline was added. The mixture was refluxed for $0.5 \mathrm{~h}$. After the time $0.0022 \mathrm{~mol}$ of the suitable amine (4-benzylpiperazine or 4-(2-phenylethyl)piperazine) were added, again refluxed for $10 \mathrm{~h}$. Then the solvents were evaporated completely under reduced pressure. The residue was purified by crystallization from the solvent (ethanol and $n$-hexane).

${ }^{1} \mathrm{H}$ NMR spectra were obtained on a $300 \mathrm{MHz}$ Brucker instrument. The samples were prepared by dissolving $5 \mathrm{mg}$ of each form in $600 \mu \mathrm{l}$ of $\mathrm{CDCl}_{3}$. IR spectra $\left(\mathrm{KBr} \mathrm{cm}{ }^{-1}\right)$ were recorded on a Specord M 80 (Carl Zeiss, Jena). Elemental analyses were run on a Carlo Erba NA 1500 analyser and the results were within $\pm 0.4 \%$ of the values calculated for the corresponding formulas. The experimental data are shown in Table 1.

\section{Differential thermal analysis}

The DSC traces were recorded on a Mettler Toledo DCS 25 measuring cell with TC15 TA Controller, calibrated with indium to ensure the accuracy of the calorimetric scale. Samples weighing 3-4 mg were characterized in sealed $40 \mu \mathrm{L}$ aluminium pans with perforated lids and subjected to thermal analysis under a flowing argon atmosphere $\left(30 \mathrm{~cm}^{3} \mathrm{~min}^{-1}\right)$. Analysis was carried out from $303 \mathrm{~K}$ to about $15^{\circ}$ above melting temperature using heating rates of 5 and $10 \mathrm{~K} \mathrm{~min}^{-1}$ with an identical empty sample pan as reference.

\section{Results and discussion}

In the IR spectra, all four compounds are clearly shown characteristic peaks of imide's carbonyl groups at 1715 (1720) and $1770(1775) \mathrm{cm}^{-1}$. We observe also benzene's peaks at 695 (705) and $750(755) \mathrm{cm}^{-1}$. However, we do not observe any peaks at $3050-3180 \mathrm{~cm}^{-1}$, where the peak of imide's N-H occurred, before condensation with suitable piperazine.

The NMR spectra all four compounds have characteristic signals of piperazines, benzenes and other protons. In NMR spectrum of compound $\mathbf{1}$, we can see multiple signal of piperazine's eight protons at 2.45-2.67 ppm, single signal of three protons from $\mathrm{CH}_{3}$ (at 6) at $2.63 \mathrm{ppm}$, single signal of two protons from $\mathrm{CH}_{2}$ (by benzene) at $3.48 \mathrm{ppm}$, single signal of three protons from $\mathrm{OCH}_{3}$ at $4.13 \mathrm{ppm}$, single signal of two protons from $\mathrm{CH}_{2}$ at $4.62 \mathrm{ppm}$ and multiple signal of benzene's six protons at 7.18-7.26 ppm. In NMR spectrum of compound 2 , we can see triple signal of three protons from $\mathrm{OCH}_{2} \mathrm{CH}_{3}$ at $1.42-1.47$ ppm, multiple signal of piperazine's eight protons at $2.43-2.65 \mathrm{ppm}$, single signal of three protons from $\mathrm{CH}_{3}$ (at 6) at $2.59 \mathrm{ppm}$, single signal of two protons from $\mathrm{CH}_{2}$ (by benzene) at $3.45 \mathrm{ppm}$, multiple signal of four protons from $\mathrm{OCH}_{2} \mathrm{CH}_{3}$ and $\mathrm{CH}_{2}$ at 4.55-4.62 ppm and multiple signal of benzene's six protons at 7.13-7.25 ppm. In NMR spectrum of compound 3, we can see multiple signal of fifteen protons from piperazine, $\mathrm{CH}_{3}$ (at 6) and $\mathrm{CH}_{2} \mathrm{CH}_{2}$-benzene at 2.55-2.73 ppm, single signal of three protons from $\mathrm{OCH}_{3}$ at $4.14 \mathrm{ppm}$, single signal of two protons from $\mathrm{CH}_{2}$ at $4.64 \mathrm{ppm}$, and multiple signal of benzene's six protons at 7.15-7.29 ppm. In NMR spectrum of compound $\mathbf{4}$, we can see triple signal of three protons of $\mathrm{OCH}_{2} \mathrm{CH}_{3}$ at 1.44-1.49 ppm, multiple signal of fifteen protons of piperazine, $\mathrm{CH}_{3}$ (at 6) and $\mathrm{CH}_{2} \mathrm{CH}_{2}$ benzene at 2.61-2.74 ppm, multiple signal of four protons from $\mathrm{OCH}_{2} \mathrm{CH}_{3}$ and $\mathrm{CH}_{2}$ at $4.57-4.64$ ppm and multiple
Fig. 11 2-(4-phenylmethyl-1piperazinyl)-methyl-4-methoxy6-methyl-1H-pyrrolo[3,4c]pyridine-1,3(2H)-dione, 2 2-(4-phenylmethyl-1piperazinyl)-methyl-4-ethoxy-6methyl-1H-pyrrolo[3,4c]pyridine-1,3(2H)-dione, 3 2-(4-phenylethyl-1piperazinyl)-methyl-4-methoxy6-methyl-1H-pyrrolo[3,4c]pyridine-1,3(2H)-dione, 4 2-(4-phenylethyl-1piperazinyl)-methyl-4-ethoxy-6methyl-1H-pyrrolo[3,4c]pyridine-1,3(2H)-dione

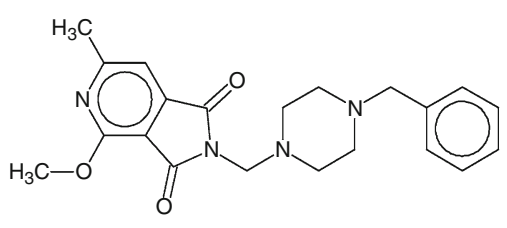

1<smiles>CCOc1nc(C)cc2c1C(=O)N(CN1CCN(Cc3ccccc3)CC1)C2=O</smiles>

2<smiles>COc1nc(C)cc2c1C(=O)N(CN1CCN(CCc3ccccc3)CC1)C2=O</smiles>

3<smiles>CCOc1nc(C)cc2c1C(=O)N(CN1CCN(CCc3ccccc3)CC1)C2=O</smiles> 
Table 1 Experimental data for compounds 1-4

\begin{tabular}{|c|c|c|c|c|c|c|}
\hline \multirow[t]{2}{*}{ Compound } & \multirow{2}{*}{$\begin{array}{l}\text { Formula } \\
\text { (molecular } \\
\text { weight) }\end{array}$} & \multirow[t]{2}{*}{$\begin{array}{l}\text { M.p./K } \\
\text { (solvent) }\end{array}$} & \multirow[t]{2}{*}{$\begin{array}{l}\text { Yield/ } \\
\%\end{array}$} & \multicolumn{2}{|c|}{$\begin{array}{l}\text { IR absorption } \\
\text { in } \mathrm{KBr} / \mathrm{cm}^{-1}\end{array}$} & \multirow[t]{2}{*}{${ }^{1} \mathrm{H}$ NMR spectra } \\
\hline & & & & $\overline{\mathrm{C}}=\mathrm{O}$ & Benzene & \\
\hline \multirow[t]{2}{*}{1} & \multirow{2}{*}{$\begin{array}{l}\mathrm{C}_{21} \mathrm{H}_{24} \mathrm{~N}_{4} \mathrm{O}_{3} \\
\quad(380.43)\end{array}$} & \multirow[t]{2}{*}{$431-434$} & \multirow[t]{2}{*}{91} & 1715 & 705 & \multirow{2}{*}{$\begin{array}{l}\text { 2.45-2.67 (m-8H, } \mathrm{H} \text { of piperazine }) ; 2.63\left(\mathrm{~s}-3 \mathrm{H}, \mathrm{CH}_{3} \text { at } 6\right) ; 3.48(\mathrm{~s}-2 \mathrm{H}, \\
\mathrm{CH}_{2} \text {-benzene); } 4.13\left(\mathrm{~s}-3 \mathrm{H}, \mathrm{OCH}_{3}\right) ; 4.62\left(\mathrm{~s}-2 \mathrm{H}, \mathrm{CH}_{2}\right) ; 7.18-7.26(\mathrm{~m}-6 \mathrm{H} \text {, } \\
\text { arom. } \mathrm{H})\end{array}$} \\
\hline & & & & 1770 & 750 & \\
\hline \multirow[t]{2}{*}{2} & \multirow{2}{*}{$\begin{array}{c}\mathrm{C}_{22} \mathrm{H}_{26} \mathrm{~N}_{4} \mathrm{O}_{3} \\
(394.46)\end{array}$} & \multirow[t]{2}{*}{$429-432$} & \multirow[t]{2}{*}{85} & 1720 & 705 & \multirow{2}{*}{$\begin{array}{l}1.42-1.47\left(\mathrm{t}-3 \mathrm{H}, \mathrm{OCH}_{2} \mathrm{CH}_{3}\right) ; 2.43-2.65(\mathrm{~m}-8 \mathrm{H}, \mathrm{H} \text { of piperazine }) ; 2.59(\mathrm{~s}- \\
\left.3 \mathrm{H}, \mathrm{CH}_{3} \text { at } 6\right) ; 3.45\left(\mathrm{~s}-2 \mathrm{H}, \mathrm{CH}_{2} \text {-benzene }\right) ; 4.55-4.62\left(\mathrm{~m}-4 \mathrm{H}, \mathrm{OCH}_{2} \mathrm{CH}_{3}\right. \\
\left.\text { and } \mathrm{CH}_{2}\right) ; 7.13-7.25(\mathrm{~m}-6 \mathrm{H}, \text { arom. } \mathrm{H})\end{array}$} \\
\hline & & & & 1775 & 750 & \\
\hline \multirow[t]{2}{*}{3} & \multirow{2}{*}{$\begin{array}{c}\mathrm{C}_{22} \mathrm{H}_{26} \mathrm{~N}_{4} \mathrm{O}_{3} \\
(394.46)\end{array}$} & \multirow[t]{2}{*}{$405-407$} & \multirow[t]{2}{*}{78} & 1715 & 695 & \multirow{2}{*}{$\begin{array}{l}2.55-2.73\left(\mathrm{~m}-15 \mathrm{H}, \mathrm{H} \text { of piperazine, } \mathrm{CH}_{3} \text { at } 6 \text { and } \mathrm{CH}_{2} \mathrm{CH}_{2} \text {-benzene }\right) ; 4.14 \\
\left(\mathrm{~s}-3 \mathrm{H}, \mathrm{OCH}_{3}\right) ; 4.64\left(\mathrm{~s}-2 \mathrm{H}, \mathrm{CH}_{2}\right) ; 7.15-7.29(\mathrm{~m}-6 \mathrm{H}, \text { arom. } \mathrm{H})\end{array}$} \\
\hline & & & & 1775 & 755 & \\
\hline \multirow[t]{2}{*}{4} & \multirow{2}{*}{$\begin{array}{c}\mathrm{C}_{23} \mathrm{H}_{28} \mathrm{~N}_{4} \mathrm{O}_{3} \\
(408.49)\end{array}$} & \multirow[t]{2}{*}{$370-373$} & \multirow[t]{2}{*}{66} & 1720 & 705 & \multirow{2}{*}{$\begin{array}{l}1.44-1.49\left(\mathrm{t}-3 \mathrm{H}, \mathrm{OCH}_{2} \mathrm{CH}_{3}\right) ; 2.61-2.74\left(\mathrm{~m}-15 \mathrm{H}, \mathrm{H} \text { of piperazine, } \mathrm{CH}_{3} \text { at } 6\right. \\
\text { and } \mathrm{CH}_{2} \mathrm{CH}_{2} \text {-benzene); } 4.57-4.64\left(\mathrm{~m}-4 \mathrm{H}, \mathrm{OCH}_{2} \mathrm{CH}_{3} \text { and } \mathrm{CH}_{2}\right) \text {; } \\
\text { 7.15-7.28 (m-6H, arom. } \mathrm{H})\end{array}$} \\
\hline & & & & 1775 & 750 & \\
\hline
\end{tabular}

signal of benzene's six protons at 7.15-7.28 ppm. While we cannot find signals at 7.74 and $10.47 \mathrm{ppm}$, where before condensation with proper piperazine was presented proton of imide nitrogen. So we can conclude, that synthesis those four new compound is successfully ended.

Finally elemental analysis confirms these four structures: compound 1 Anal. Calcd for $\mathrm{C}_{21} \mathrm{H}_{24} \mathrm{~N}_{4} \mathrm{O}_{3}$ : C, 66.30; $\mathrm{H}, 6.36$; N, 14.73. Found: C, 66.39; H, 6.33; N, 14.37, compound 2: Anal. Calcd for $\mathrm{C}_{22} \mathrm{H}_{26} \mathrm{~N}_{4} \mathrm{O}_{3}$ : C, 67.00; H, 6.64; N, 14.20. Found: C, 67.40; H, 6.73; N, 14.10, compound 3: Anal. Calcd for $\mathrm{C}_{22} \mathrm{H}_{26} \mathrm{~N}_{4} \mathrm{O}_{3}: \mathrm{C}, 67.00 ; \mathrm{H}, 6.64$; N, 14.20. Found: C, 66.67; H, 6.47; N, 13.94., compound 4: Anal. Calcd for $\mathrm{C}_{23} \mathrm{H}_{28} \mathrm{~N}_{4} \mathrm{O}_{3}$ : C, 67.62; H, 6.91; N, 13.72 . Found: C, 67.93; H, 7.05; N, 14.03 .

Heat flow versus temperature has been measured for four compounds in numerous experimental runs. In the first step, samples were heated with $5 \mathrm{~K} \mathrm{~min}^{-1}$ rate, to complete melting. Then heating was continued up to the decomposition. The values of the melting point and purity determined from these scans using the Purity option software based on van't Hoff equation (Table 2).
The temperature values of melting point are in a very good agreement with the results obtained by elemental analysis (Table 1). The DSC curves show only one endothermic peak corresponding to the melting of pure compounds. The differences in melting temperatures of compounds obtained from different solvents are within the limits of error, so it seems that solvent has no effect on the crystallization of the compound. New samples of all substances sealed in ampoules and stored 1 year at room temperature. After this time, they were measured by the DSC method. The melting temperature and purity are determined. For compounds 1, 2 and 4, temperature and purity values are in a very good accordance with the data obtained from the experiments carried out 1 year ago (Table 2). Enthalpies of melting for compounds obtained from different solvents and after 1 year of storage were also determined. The values for each DSC scan are comparable: $82.3,81.9$ and $80.4 \mathrm{Jg}^{-1}$ for compound $\mathbf{1}$ (ethanol, $n$-hexane, 1 year, respectively); $96.7,96.1$ and $95.4 \mathrm{Jg}^{-1}$ for compound $2 ; 61.0,62.6$ and $60.1 \mathrm{Jg}^{-1}$ for compound 4 . The results indicated that those compounds are stable

Table 2 DSC data for compound 1-4

\begin{tabular}{llllll}
\hline Compound & M.p./K (solvent) & Purity/\% & Decomposition/K & $\begin{array}{l}\text { M.p./K (solvent) } \\
\text { After 1 year }\end{array}$ & $\begin{array}{l}\text { Purity/\% } \\
\text { After 1 year }\end{array}$ \\
\hline $\mathbf{1}$ & 431.1 (Ethanol) & $99.2 \%$ & 478.5 & 431.1 (Ethanol) & $99.1 \%$ \\
& 431.0 (n-Hexane) & $99.4 \%$ & & $431.0(n$-Hexane) & $99.2 \%$ \\
$\mathbf{2}$ & 429.9 (Ethanol) & $99.1 \%$ & 500.9 & 429.9 (Ethanol) & $99.0 \%$ \\
& $430.0(n$-Hexane) & $99.3 \%$ & & $430.1(n$-Hexane) & $99.1 \%$ \\
$\mathbf{3}$ & 402.6 (Ethanol) & $99.3 \%$ & 477.2 & $400.9,415.1($ Ethanol) & $99.0 \%$ \\
& 403.3 (n-Hexane) & $99.2 \%$ & & $401.2,414.4(n$-Hexane) & $98.8 \%$ \\
& 369.4 (Ethanol) & $99.4 \%$ & 511.8 & 369.4 (Ethanol) & $99.2 \%$ \\
\hline
\end{tabular}


Fig. 2 DSC traces at

$5 \mathrm{~K} \mathrm{~min}^{-1}$ for compound 2 (obtained from $n$-hexane and ethanol)

Fig. 3 DSC heating curves $5 \mathrm{~K} \mathrm{~min}^{-1}$ for compound 3 (obtained from $n$-hexane and ethanol)

Fig. 4 DSC heating curves $5 \mathrm{~K} \mathrm{~min}^{-1}$ for compound 3 (first heating and heating after rapid cooling)
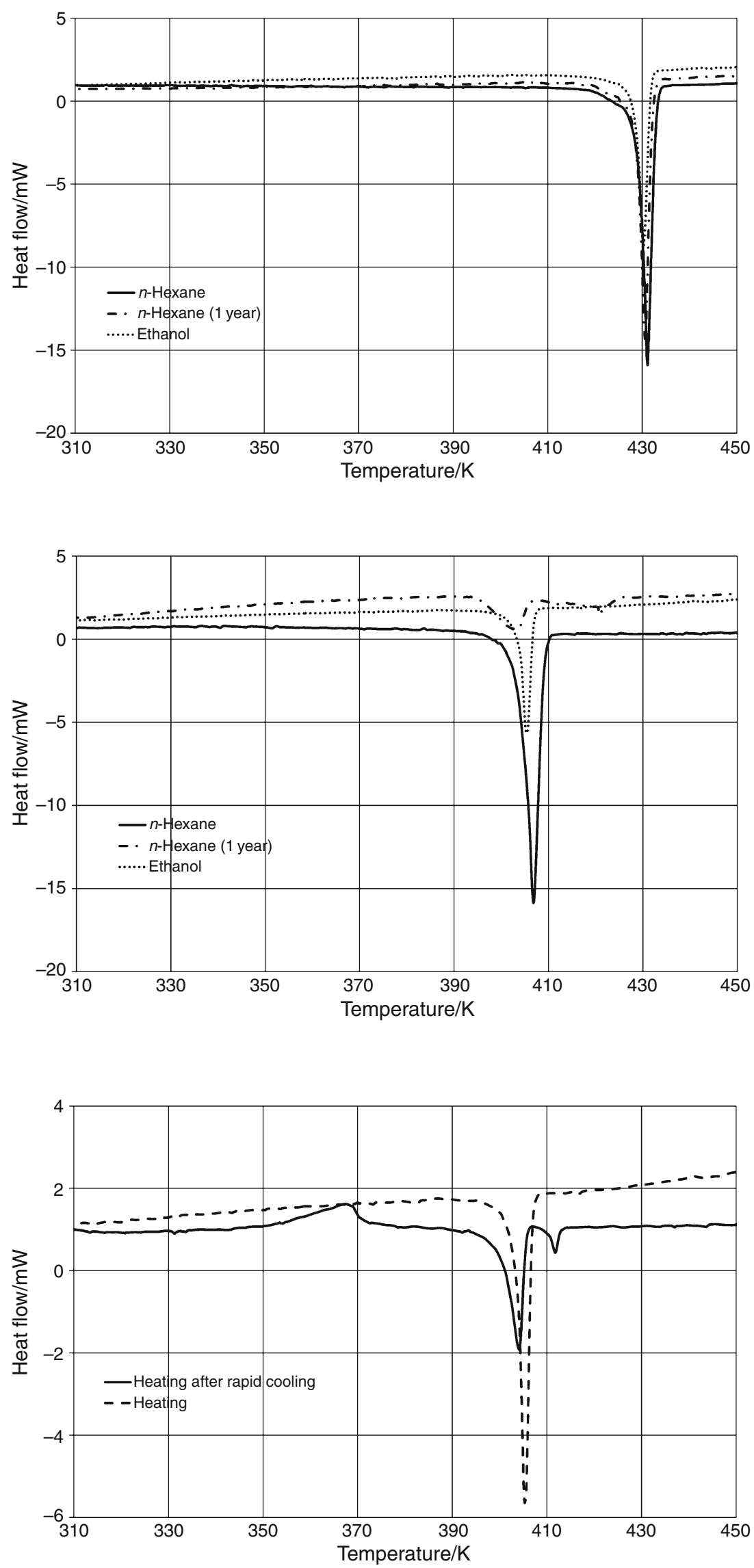
during storage. The DSC scans illustrating these experiments are shown on Fig. 2 (for compound 2).

The DSC curves measured for the compound $\mathbf{3}$ obtained from ethanol, $n$-hexane and after 1 year storage are shown on Fig. 3. The results for compound $\mathbf{3}$ are different than that for compounds $\mathbf{1}, \mathbf{2}$ and $\mathbf{4}$. There is one exothermic thermal effect on the DSC curve for the samples crystallized from different solvents, at $402.6 \mathrm{~K}$ (ethanol) and $403.3 \mathrm{~K}$ ( $n$-hexane). The enthalpies of melting are similar: $78.7 \mathrm{Jg}^{-1}$ (ethanol) and $75.1 \mathrm{Jg}^{-1}$ (n-hexane). The results seem to indicate that the choice of solvent has no influence on the crystallization of compound 3. The DSC measurement of the sample stored about a year showed two exothermic peaks at 400.9 and $415.1 \mathrm{~K}$ (ethanol). A lower value is almost identical to the temperature obtained for the samples crystallized from ethanol or $n$-hexane. For thermal effect of this temperature, the value of enthalpy is equal to $46.1 \mathrm{Jg}^{-1}$, it is about $60 \%$ lower than for the sample measured a year ago. Two thermal effects on the DSC scan can be due to partial decomposition of compound or phase transition from the metastable form to the stable one during the storage.

In accordance with Ostwald's rule, the less stable modifications are often formed first on the crystallizing process from the melt. These rearrange then stepwise to the stable form. Quite often, it is easier to obtain metastable forms by slowly heating amorphous material (obtained by shock cooling from the melt) above the glass transition temperature $[12,26]$. This procedure carried out for all compounds.

The DSC scans for compound $\mathbf{3}$ are showed on Fig. 4. In the first step, a sample is heated above melting temperature with heating rate $5 \mathrm{~K} \mathrm{~min}^{-1}$ (dashed curve). One exothermic thermal effect at temperature $400.9 \mathrm{~K}$ is observed. After a shock cooling, the second measurement was carried out. If the melting is rapid cooled quite often, instead of crystals, glass is formed. On heating again at $5 \mathrm{~K} \mathrm{~min}^{-1}$ a few thermal effects are observed. A single endothermic peak has been detected at $365.1 \mathrm{~K}$ due to cold crystallization. On further heating the DSC trace shows two exothermic peaks at 401.7 and $411.3 \mathrm{~K}$ corresponding to the melting. It seems that this result is similar to that after storage one (Fig. 3). This surprising result may suggest that it is possible to say that the compound $\mathbf{3}$ has two crystal forms: metastable modification and stable modification. However, we were unable to obtain a sample containing only stable form.

For compounds 1, 2 and $\mathbf{4}$ after heating and shock cooling, the thermal effects are not detected on the DSC curves. Those experiments were carried out immediately after rapid cooling, after a week and after a month. In all cases, no thermal effects were observed. The rapid cooling of a liquid below its melting point may lead to an amorphous state with structural characteristics of a liquid. Since molecules in the amorphous state are thermodynamically metastable relative to the crystalline state, the potential for crystallization during handling and storage is always present. However, the temperature at which optimal nucleation and hence crystallization should occur will depend on the degree below melting point and where the temperature lies relative to glass transition temperature [27-33]. At storage temperatures near to and above glass transition, the rates of crystallization increased. On the other hand, the temperature dependence of molecular motions below the glass transition temperature is highly dependent upon conditions under which the glass was formed [27, 34-38]. Those molecular motions are consequences of relaxation of a sample.

\section{Conclusions}

The derivatives of 3,4-pyridinedicarboximide are very interesting materials due to their analgesic activity. In this study, the DSC has been used to solid-state characterization of four new compounds. The important aspects of our investigation were stability and tendency or conditions for crystallization in different crystalline forms (monotropic polymorphism). The thermal analysis and calorimetric methods offer great advantages for the study of polymorphism and pseudo-polymorphism. Only a few milligrams of a sample per experiment are necessary. However, transitions of small energies or polymorphs are often not detected. On the other hand, an amorphous solid with long relaxation time is often obtained. In some cases, it may be impossible to crystallize the material. From among the four studied compounds, probably only the compound number $\mathbf{3}$ may occur different polymorphic form. DSC studies showed significant differences during the rapid cooling (crystallization). The rapid cooling did not cause re-crystallization of compounds $\mathbf{1}, 2$ and $\mathbf{4}$. It should be noted, however, that the crystallization of the amorphous form depends on both barrier to crystallization and molecular mobility [32]. On the other hand, only for the compound 3 measurements showed differences on the DSC curves after a long-time storage (and only the compound $\mathbf{3}$ showed the two exothermic effects on heating curves after rapid cooling) probably due to two crystal forms: the metastable modification and stable one. The stability of compounds $\mathbf{1}$, $\mathbf{2}$ and $\mathbf{4}$ after 1 year storage, to some extent indicates a lack of the polymorphs forms.

Acknowledgements The study was supported by research fellowship within "Development program of Wroclaw Medical University" funded from European Social Fund, Human Capital, National Cohesion Strategy (Contract No. UDA-POKL.04.01.01-00-010/08-01). 
Open Access This article is distributed under the terms of the Creative Commons Attribution Noncommercial License which permits any noncommercial use, distribution, and reproduction in any medium, provided the original author(s) and source are credited.

\section{References}

1. Śladowska H, Potoczek J, Sieklucka-Dziuba M, Semczuk A, Kleirok Z. Synthesis, chemical and pharmacological properties of some $\mathrm{N}$-aminoalkyl derivatives of 3,4-pyridinedicarboximides. Farmaco. 1995;50:761-8.

2. Śladowska H, Potoczek J, Rajtar G, Sieklucka-Dziuba M, Zółkowska D, Kleinrok Z. Investigations on the synthesis and properties of some $N$-[4-phenyl(2-pyrimidinyl)-1-piperazinyl]alkyl(hydroxyalkyl)-3,4-pyridinedicarboximides. Acta Pol Pharm Drug Res. 1996;33:417-24.

3. Śladowska H. Investigations on the synthesis and properties of $\mathrm{N}$ aryl(heteroaryl) piperazinylalkyl derivatives of imide of 6-methyl-2-(1-piperydino)-3,4-pyridinedicar-boxylic acid. Farmaco. 1994;49:493-8.

4. Śladowska H, Filipek B, Szkatuła D, Sabiniarz A, Kardasz M, Potoczek J, Sieklucka-Dziuba M, Rajtar G, Kleinrok Z, Lis T. Investigations on the synthesis and pharmacological properties of 4-alkoxy-2-[2-hydroxy-3-(4-aryl-1-piperazinyl)-propyl]-6methyl-1H-pyrrolo[3,4-c]pyridine-1,3(2H)-diones. Farmaco. 2002;57:897-908.

5. Śladowska H, Filipek B, Szkatuła D, Sapa J, Bednarski M, Ciołkowska M. Investigations on the synthesis and pharmacological properties of $\mathrm{N}$-substituted derivatives of 4-alkoxy-6methyl-1H-pyrrolo[3,4-c]pyridine-1, 3(2H)-diones. Farmaco. 2005; 60:53-9.

6. Muszalska I, Śladowska H, Szkatuła D. A validated spectrophotometric and liquid chromatography method for determination and purity evaluation of 4-methoxy-2-[2-hydroxy-3(4-phenyl-1piperazinyl)]propyl-2,3-dihydro-6-methyl-1,3-dioxo-1H-pyrrolo[3,4-c]pyridine. Farmaco. 2003;58:513-9.

7. Muszalska I. Kinetics of hydrolysis of 4-methoxy-2-[2-hydroxy3(4-phenyl-1-piperazinyl)]propyl-2,3-dihydro-6-methyl-1,3dioxo-1H-pyrrolo[3,4-c]pyridine in aqueous solutions. Farmaco. 2004;59:437-42.

8. Muszalska I, Śladowska H, Sabiniarz A. HPLC and TLC methodology for determination or purity evaluation of 4-methoxy-2[3(4-phenyl-1-piperazinyl)]-propyl-2,3-dihydro-6-methyl-1,3dioxo-1H-pyrrolo[3,4-c]pyridine. Acta Pol Pharm Drug Res. 2005;62:3-10.

9. Ford JL, Timmins P. Pharmaceutical thermal analysis: techniques and applications. New York: Wiley; 1989.

10. Haines PJ. Thermal methods of analysis-principles, applications and problems. London: Blackie Academic and Professional; 1995.

11. Charsley EL, Warrington SB. Thermal analysis: techniques and applications. Cambrigde: Royal Society of Chemistry; 1992.

12. Craig DQM. Thermal analysis of pharmaceuticals. Reading: CRC Press; 2007

13. Giron D. Applications of thermal analysis and coupled techniques in pharmaceutical industry. J Therm Anal Calorim. 2002;68(2): 335-57.

14. Cides LCS, Araújo AAS, Santos-Filho M, Matos JR. Thermal behaviour, compatibility study and decomposition kinetics of glimepiride under isothermal and non-isothermal conditions. J Therm Anal Calorim. 2006;84:441-5.

15. Xu F, Sun LX, Tan ZC, Liang JG, Zhang T. Adiabatic calorimetry and thermal analysis on acetaminophen. J Therm Anal Calorim. 2006;83:187-91.
16. Ndlebe VJ, Brown ME, Glas BD. The thermal stability of triprolidine hydrochloride and its mixtures with cyclodextrin and glucose. J Therm Anal Calorim. 2004;77:445-57.

17. Giron D, Mutz M, Garnier S. Solid-state of pharmaceutical compounds-impact of the ICH Q6 guideline on industrial development. J Therm Anal Calorim. 2004;77:709-47.

18. Macedo RO, de Nascimento G, Veras JWE. Compatibility and stability studies of propranolol hydrochloride binary mixtures and tablets for TG and DSC-photovisual. J Therm Anal Calorim. 2002;67:483-9.

19. Drebushchak VA, Shakhtshneider TP, Apenina SA, Medvedeva AS, Safronova LP, Boldyrev VV. Thermoanalytical investigation of drug-excipient interaction. J Therm Anal Calorim. 2006;86: 303-9.

20. Malpezzi L, Fuganti C, Maccaroni E, Masciocchi N, Nardi A. Thermal and structural characterization of two polymorphs of Atovaquone and of its chloro derivative. J Therm Anal Calorim. 2010;102:201-3.

21. Sovizi MR. Thermal behavior of drugs. Investigation on decomposition kinetic of naproxen and celecoxib. J Therm Anal Calorim. 2010;102:285-9.

22. Paukov IE, Kovalevskaya YA, Boldyreva EV. Low-temperature thermodynamic properties of DL-cysteine. J Therm Anal Calorim. 2010;100:295-301.

23. Picciochi R, Diogo HP, Minas da Piedade ME. Thermochemistry of paracetamol. J Therm Anal Calorim. 2010;100:391-401.

24. Parfenyuk EV, Kulikova GA, Ryabinina IV. DSC and spectroscopic investigation of human serum albumin adsorbed onto silica nanoparticles functionalized by amino groups. J Therm Anal Calorim. 2010;100:987-91.

25. Szterner P, Legendre B, Sghaier M. Thermodynamic properties of polymorphic forms of theophylline. Part I: DSC, TG, X-ray study. J Therm Anal Calorim. 2010;99:325-35.

26. Giron D. Thermal analysis and calorimetric methods in the characterisation of polymorphs and solvates. Thermochim Acta. 1995;248:1-59.

27. Hancock BC, Zografi G. Characteristics and significance of the amorphous state in pharmaceutical systems. J Pharm Sci. 1997;86(1): $1-12$.

28. Hancock BC, Parks M. What is the true solubility advantage for amorphous pharmaceuticals? Pharm Res. 2000;17(4):397-404.

29. Graeser KA, Patterson JE, Zeitler JA, Gordon KC, Rades T. Correlating thermodynamic and kinetic parameters with amorphous stability. Eur J Pharm Sci. 2009;37(3-4):492-5.

30. Adrjanowicz K, Wojnarowska Z, Włodarczyk P, Kaminski K, Paluch M, Mazgalski J. Molecular mobility in liquid and glassy states of Telmisartan (TEL) studied by broadband dielectric spectroscopy. Eur J Pharm Sci. 2009;38(5):395-404.

31. Yu L. Amorphous pharmaceutical solids: preparation, characterization and stabilization. Adv Drug Deliv Rev. 2001;48(1): $27-42$.

32. Zhou DL, Zhang GGZ, Law D, Grant DJW, Schmitt EA. Physical stability of amorphous pharmaceuticals: importance of configurational thermodynamic quantities and molecular mobility. J Pharm Sci. 2002;91(8):1863-72.

33. Kawakami K, Pikal MJ. Calorimetric investigation of the structural relaxation of amorphous materials: evaluating validity of the methodologies. J Pharm Sci. 2005;94(5):948-65.

34. Van Eerdenbrugh B, Baird JA, Taylor LS. Crystallization tendency of active pharmaceutical ingredients following rapid solvent evaporation-classification and comparison with crystallization tendency from undercooled melts. J Pharm Sci. 2010;9091(9): 3826-38.

35. Bhugra C, Pikal MJ. Role of thermodynamic, molecular and kinetic factors in crystallization from the amorphous state. J Pharm Sci. 2008;97(4):1329-49. 
36. Jójárt-Laczkovich O, Szabó-Révész P. Amorphization of a crystalline active pharmaceutical ingredient and thermoanalytical measurements on this glassy form. J Therm Anal Calorim. 2010;102:243-7.

37. Bruni G, Milanese C, Berbenni V, Sartor F, Villa M, Marini A. Crystalline and amorphous phases of a new drug. J Therm Anal Calorim. 2010;102:297-303.
38. Canotilho J, Castro RAE, Rosado MTS, Nunes SCC, Cruz MSC, Redinha JS. Thermal analysis and crystallization from melts $\beta$ adrenergic compounds. J Therm Anal Calorim. 2010;100:423-9. 